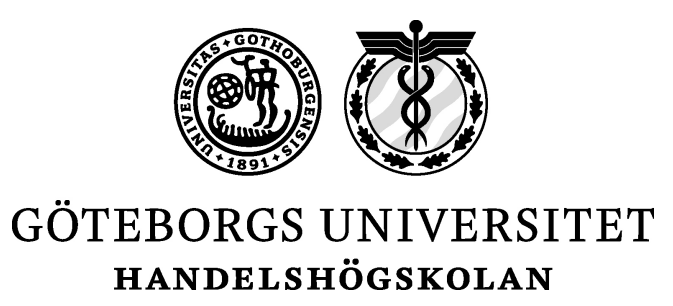

WORKING PAPERS IN ECONOMICS

No 352

Do attitudes toward gender equality really differ between Norway and Sweden?

Niklas Jakobsson and Andreas Kotsadam

October 2009

ISSN 1403-2473 (print)

ISSN 1403-2465 (online) 


\title{
Do attitudes toward gender equality really differ between Norway and Sweden?
}

\author{
Niklas Jakobsson and Andreas Kotsadam*
}

October, 2009

\begin{abstract}
Using survey data from Norway and Sweden, we assess people's attitudes toward gender equality. Previous studies argue that these attitudes are more egalitarian in Sweden than in Norway. Similar to previous research, we find that Swedes are more positive towards gender equality in general. However, we find no differences regarding views on egalitarian sharing of household responsibilities, and Norwegians are actually more supportive of government intervention to increase gender equality. This suggests that the lower support for gender equality in Norway is not as clear-cut as previously thought and that active state intervention to improve gender equality may be even more feasible in Norway than in Sweden.
\end{abstract}

Keywords: attitudes, norms, gender equality, state intervention, household responsibility

\footnotetext{
*Norwegian Social Research; Nordic Centre of Excellence: Reassessing the Nordic Welfare Model; and Department of Economics, University of Gothenburg, Sweden, Box 640, SE-405 30 , Gothenburg, Sweden. E-mail: niklas.jakobsson@economics.gu.se and andreas.kotsadam@economics.gu.se. The paper has benefited from comments by seminar participants at Norwegian Social Research. We would also like to thank Katarina Nordblom, Olof Johansson Stenman, Lennart Flood, Viggo Nordvik, Dominique Anxo, and two anonymous referees for useful comments.
} 


\section{Introduction}

Although men and women allocate their time differently from country to country, a common trend in recent years is that women have increased the time devoted to paid work. This development has not been combined with an equivalent increase in men's time devoted to housework, often leading to gender inequalities in leisure time (Coltrane 2000). The entering of women into the public sphere (education, employment and politics) is often referred to as the first gender revolution. The second step is argued to be where men take an equal responsibility for housework and caregiving in the private sphere (e.g. Bernhardt et al. 2008). The present article investigates attitudes linked to both of these spheres in Norway and Sweden.

The Scandinavian welfare states are often grouped together in comparative welfare state research (e.g. Esping-Andersen 1990; 1999). However, while this may be fruitful in comparative research across many countries, it may also be dangerous since intra-regime differences are downplayed or ignored (Ellingsæter 1998; Kautto et al. 2001). An important example in this setting is, as Teigen and Wängnerud (2009) argue, that countries that are seen as very similar regarding gender equality (as Norway and Sweden) may differ substantially in their gender equality discourses. By analysing differences within regimes, we can gain more knowledge about crucial differences overlooked in analyses of many countries. Previous comparative research suggests that Swedes are more supportive of gender equality than Norwegians (Bernhardt et al. 2008; Ellingsæter 1998; Knudsen and Wærness 2001), and the main aim of the present paper is to problematise this finding and further investigate what the potential differences are.

Investigating what shapes values is of importance for understanding actual behaviour. For example, Fuwa (2004) finds that gender ideology at the macro level has a large impact on the division of labour for individual couples. Since the macro-level gender ideology is an aggregate of individual perceptions, these are important to grasp comprehensively. A general finding in the literature (see for instance Coltrane 2000, who reviews more than 200 academic articles and books on the topic, or Bianchi et al. 2000) is also that individual-level gender ideology is an important predictor of equal sharing of housework (although we think that the direction of causality is often not fully investigated). 
In addition, attitudes are important since they may shape (and are shaped by) welfare policies (Ellingsæter 1998; Svallfors 2007). Sjöberg (2004) argues that family policies affect gender role attitudes in two ways: by merely enabling dual earnership and by signalling what is to be seen as appropriate behaviour. Institutions thus influence world views and can be seen as normative orders. Similarly, Ferrarini (2003) argues that policies affect the agency of citizens since the bundle of choices available to individuals is altered. Svallfors (2007) argues that institutions affect human behaviour by affecting the structure of rewards and costs, and by structuring possibilities and incentives.

There are some previous studies that compare gender egalitarian values in Norway and Sweden. Using survey data, Bernhardt et al. (2008) study both ideal and reported actual sharing of housework in Norway and Sweden among young couples and find that Swedish couples are more in favour of sharing housework, and also actually share it to a greater extent than Norwegians. It is argued that the more positive attitudes and actual sharing of housework in Sweden compared to Norway is due to Sweden's longer history of egalitarian public policies. Egalitarian ideals are found to be more likely among childless couples, employed women, couples where the woman earns a high salary, highly educated people, and people who do not think it is important to have gainful employment.

In a study focusing on attitudes towards mothers' employment, Knudsen and Wrrness (2001) compare attitudes in Great Britain, Sweden and Norway. Out of the three, Swedes are the most positive towards mothers' employment, while Norwegians are the most negative. Women, younger people, those with more education and non-religious individuals are more positive towards mothers' employment in all three countries. Ellingsæter (1998) looks at people's personal attitudes towards the economic provision among parents along with how they believe other people feel in this regard, and also look at the linkages between perceptions and attitudes in Sweden, Denmark and Norway. She finds that Swedish parents perceive that other Swedes want more economic equality than Danish and Norwegian parents perceive that their respective compatriots want. Regarding attitudes on shared childcare, Swedes are again found to be more egalitarian. The important determinants for these attitudes were found to be gender (females were more egalitarian), time availability, and 
the existence of children in the household (although only significantly negatively correlated with egalitarian values in Norway).

The specific national context is also argued to be an important factor in explaining the gender division of housework (Batalova and Cohen 2002; Fuwa 2004; Fuwa and Cohen 2007; Hook 2006; Knudsen and Wrrness 2008). More exactly, it is thought to affect the opportunity costs for men and women and also interact with individual level characteristics. The argument is that an individual woman's power is nested in the macro level and it is not only that individual women might negotiate better given the micro conditions, but also that the effects of micro level factors become modified due to macro factors (Fuwa 2004). Hook (2006) shows that in countries where female labour-force participation is high, single men are more involved in housework, possibly due to differences in attitudes. The argument is supported by the significance of the macro level female employment rate even after controlling for time availability and relative resources and that the general female employment rate is significant even for singles. To understand why there may exist attitude differences between Norway and Sweden, which are not explained by compositional factors, thereby requires an understanding of macro level differences between the countries. Several explanations have been suggested in the previous literature. Teigen and Wängnerud (2009) find that Norwegians are more prone to use liberal feminist explanations, while Swedes more often use radical feminist explanations. ${ }^{1}$ Ellingsæter (1998) claims that urbanisation was faster in Sweden than in Norway, combined with a geographically clustered working class, this led to a strong labour movement and finally a social-democratic hegemony that is argued to have affected values in a progressive way. Finally, Bernhardt et al. (2008) argue that the differences between the countries are due to divergent policy histories.

Summing up the previous studies, there seems to be a tendency towards more positive attitudes towards gender equality in general, as well as more equal practises. It is also the case that people in the Nordic countries stand out as being more positive towards gender equality than others and that Swedes are even more positive than Norwegians. There is also support for the notion that attitudes towards gender equality matter for actual outcomes. The aim of this paper is to investigate whether there are differences in attitudes toward gender equality between Norway and Sweden. Previous studies all find that Swedes are more egalitarian than 
Norwegians (both concerning practices and attitudes) and different reasons have been put forward as to why a difference between the countries is expected. Some of the previous explanations focus on compositional effects (e.g. that Norwegians are more religious) and other focus more on macro level differences (e.g. policies and cultural paradigms) (Bernhardt et al. 2008; Ellingsæter 1998; and Knudsen and Wærness 2008). In this study, we can further assess the differences in attitudes towards gender equality between Norway and Sweden. This is done not only by looking at general attitudes towards gender equality and attitudes towards egalitarian sharing of household responsibilities, but also by considering attitudes towards government intervention to increase gender equality in family life. Our questions are: Are there still differences in gender egalitarian attitudes between Norway and Sweden? Do these differences depend on which questions are being asked, the aspect of gender equality highlighted, or the area of social life considered?

Our study is an important contribution to the literature on gender equality attitudes in Norway and Sweden since it is more general than former studies. Bernhardt et al. (2008) investigate people's attitudes towards sharing housework (as well as actual practice) in Norway and Sweden. Their study includes only young (22-35 years) individuals and individuals living with a partner. Ellingsæter (1998) uses data from 1993 to investigate attitudes regarding whether the man or the woman should be the main breadwinner in a household, but the study only includes employed couples aged 20 to 54 years. Knudsen and Wærness (2001) investigate attitudes towards mothers' being employed among respondents aged 20 to 70 years in Great Britain, Norway and Sweden using data from 1994. Compared to these studies, our study investigates a broader spectrum of questions related to different aspects of gender equality. By using a large sample from 2008 of respondents aged 15 to 65, both singles and individuals living with a partner, we are able to capture attitudes towards gender equality more generally. This study should therefore be able to provide a more accurate presentation of current attitudes towards gender equality in Norway and Sweden. Similar to previous research, we find that Swedes are more positive towards gender equality. However, we find no differences in views on egalitarian sharing of household responsibilities, and Norwegians are actually more supportive of government policies to increase gender equality. Hence, there seem to be greater possibilities of actually implementing policies that promote gender equality in Norway than in Sweden, and the 
general result in previous research of more egalitarian gender norms in Sweden than in Norway is partly contested.

Section 2 describes the survey and descriptive statistics, Section 3 reports the empirical results, Section 4 takes a closer look at the differences between Norway and Sweden, and Section 5 concludes the paper.

\section{Data and descriptive statistics}

In August 2008, TNS Gallup was hired to send out an Internet-based survey to a random sample of 2500 Norwegians and 3000 Swedes aged 15-65; 1716 Norwegians (68.6\%) and $1815(60.5 \%)$ Swedes responded. The survey included three main questions regarding attitudes towards gender equality: 'Do you think that gender equality is important?', 'Is it important that the man and the woman share the responsibility for the household?', and 'Do you think that the government should try to influence family life to increase gender equality, e.g. by subsidies or laws?'. The respondents could respond to these questions on 0-10 scales where 0 indicated 'No, not at all' and 10 indicated 'Yes, for sure'.

Figures 1, 2 and 3 show the responses to the questions with histograms for each country separately. As can be seen, there is indeed variation in the expressed attitudes, not only within each country but also between the countries. Figure 1 shows that considerably more Swedes than Norwegians answer 10 on the question regarding gender equality (Gendereq), i.e., more Swedes think it is very important. The situation is similar but not as pronounced for the question on sharing household responsibilities (Sharing) (Figure 2). Figure 3 shows that the picture is different for the government intervention variable (Intervention): more Swedes answer 0 and more Norwegians answer 10, i.e. Norwegians seem to be more positive towards government intervention to increase gender equality in family life. A Wilcoxon ranksum test was carried out to test whether the differences are statistically significant, and this revealed that the differences in Gendereq and Intervention between Norway and Sweden are statistically significant at $1 \%$, while the difference in Sharing is significant at $10 \%$.

[Figures 1-3] 
While Gendereq captures to what extent a respondent embraces gender equality in general, Sharing can be assumed to capture housework more specifically. Since the Sharing question is quite generally formulated (it concerns degree of responsibility rather than exactly how the work should be divided), it is possible that a respondent chooses a high value even if he/she at the same time feels that a woman and a man should not perform the same chores. Whether this makes the response a good indicator of preferences regarding gender equality can of course be discussed. Intervention captures the respondents' willingness to have the government influence family life with the purpose of increasing gender equality. A potential problem is that the question upon which this variable is based includes two stimuli: government influence and gender equality. Although this may be seen as problematic since we do not know which stimulus is the main driver for different individuals, we argue that the importance of such an explicit question outweighs the said methodological concerns. Additionally, in our regressions we control for other factors that are likely to drive attitudes on government intervention more generally, e.g. being to the left or to the right politically. These concerns are further discussed when interpreting the results.

We also asked about the respondents' religiosity, political views, age, gender, education etc. Table 1 presents descriptive statistics for the sample as well as the direction of the expected effects. Following previous research we include a number of variables to control for compositional differences between the countries and to exploit our newer data to assess the validity of some previously found effects.

Previous research finds that women are more positive towards different aspects of gender equality (e.g. Knudsen and Wærness 2008). To test and control for this we include a Male dummy in our estimations. Ellingsæter (1998) finds indications of a generational shift where younger respondents are more positive towards childcare and Knudsen and Wærness (2008) find that younger people are more positive towards mothers being employed. Age and $\underline{A g e}^{2}$ are included to test and control for this effect, and to see if the effect is linear. Child is included to account for the result from Bernhardt et al. (2008) and Ellingsæer (1998) that childless people are more likely to embrace egalitarian ideals. We also include cohabitation status since people who live together tend to split the chores in a gendered way, which may affect their attitudes towards gender equality negatively (Coltrane 2000). Previous studies 
also find evidence of highly educated, as well as high income earners, being more positive toward gender equality, these factors are also included in our study. We test and control for (by using a capital dummy) if there is an urban/rural division with gender equality norms being stronger in urban areas as suggested by Ellingsæter (1998). Bernhardt et al. 2008 also find that not working full time affects peoples' attitudes towards gender equality negatively; Fulltime and Parttime are included to account for this. Working in the public sector is a crude measure of whether a respondent works in a female dominated sector, which should have a positive effect on gender attitudes according to Ellingsæter (1998). Following Knudsen and Wærness (2008), religiousness is also expected to affect attitudes towards gender equality negatively. Right and Left are included to test and account for if political orientation affects gender attitudes and being rightwing is expected to be negatively correlated with attitudes toward gender equality.

Looking at descriptive statistics we see that $47.5 \%$ are men and the average age is 39 years. $46.0 \%$ have at least some university education, while $13.3 \%$ have only elementary education or less. $11.2 \%$ of the Norwegians and $21.4 \%$ of the Swedes live in the capital city (Oslo and Stockholm respectively). Since our youngest respondents are only 15 years old, they can not possibly have obtained the highest level of education, and it is highly unlikely that they are high income earners. This is discussed further below. Looking at national statistics, the share of men is $50.8 \%$ in Sweden and 50.9\% in Norway. This corresponds well with the Swedish sample where $50.3 \%$ of the respondents are men. However, only $44.5 \%$ of the Norwegian respondents are men. The mean ages for our age cohorts are 40.1 years in Sweden and 39.7 years in Norway, while the mean ages in our sample are 41.6 years for Swedes and 37.2 years for Norwegians (Statistics Sweden 2008 and Statistics Norway 2008). However, the representativeness of our sample is more problematic with respect to education. While the share of Swedes with higher education is $31.8 \%$ for people aged 16-65, the share in our sample is $43.4 \%$. The Norwegian numbers differ even more: $27.0 \%$ of all Norwegians aged 16-66 have university education, while in our sample the figure is $48.8 \%$. Hence, our sample is fairly representative except regarding education, where it is biased towards including highly educated people. This must be considered when comparing raw correlations and mean values. At any rate, the problem is somewhat alleviated in the regression analyses where we control for education. 
[Table 1]

\section{Empirical framework and results}

In this section we investigate what factors are associated with attitudes towards gender equality. In order to do this we run OLS regressions, although the distributions of the dependent variables are not normally distributed. This is done in order to ease the presentation of the results, but we have also estimated ordered logit models with similar results. ${ }^{2}$ The specification is:

$\mathrm{y}_{\mathrm{i}}=\beta_{0}+\beta_{1} \mathrm{x}_{\mathrm{i}}+\varepsilon_{\mathrm{i}}$

where $y_{i}$ is the attitude towards gender equality, egalitarian sharing of household responsibilities, and increased government intervention to promote gender equality, respectively (ranging from 0 for 'No, not at all' to 10 for 'Yes, for sure') for individual $i . \mathbf{x}$ is a vector of both socio-demographic and attitude variables (see Table 1). We also run stepwise regressions to see if the interpretation of the results changes due to correlations between the explanatory variables. ${ }^{3}$

Table 2 presents the regressions for our three dependent variables. As can be seen, being male is negatively correlated with all three dependent variables, i.e. men do not feel that gender equality in general and equal sharing of household responsibilities are as important as women do, nor are they as enthusiastic about the government intervening in order to increase equality in family life. Age is not significantly correlated with any of the dependent variables. ${ }^{4}$ This is interesting since it contrasts a popular opinion in the debate on gender equality that things will improve as new cohorts replace old (and by assumption more conservative) ones. It also contrasts some previous findings in the literature (e.g. Ellingsæeter 1998; and Knudsen and Wærness 2008). Since age does not seem to be of importance in our data, we also tried to use 10-year dummies to capture different birth cohorts. However, they generally turned out not statistically significant. ${ }^{5}$ It should be noted that even if we had 
found significant differences, it would have been impossible to separate cohort and age effects in this way.

[Table 2]

Cohabitation status does not seem to affect any of the three dependent variables either. This is in contrast to previous research. A possible reason for the insignificance in our specification could be that we do not only look at married people. Couples who live together but are not married are sometimes expected not to embrace marriage norms, and this may be correlated with egalitarian values (e.g. Coltrane 2000). However, we also tested for marital status with the same result as for Cohabit in Norway (in the Swedish sample we cannot distinguish between marriage and living together without being married).

Regarding education we can note that only university education seems to be important: it is positively correlated with all three dependent variables - especially with the one related to government intervention. While it is only significant at $10 \%$ for the Sharing variable, it becomes significant at the $5 \%$ level if we exclude respondents younger than 26 . That higher education is positively correlated with gender egalitarianism is in line with previous research (Bernhardt et al. 2008; Knudsen and Wærness 2001). This is usually interpreted in the literature as education itself affecting values. However, interpreting the education variable might be trickier than that, as Coltrane (2000) argues, since we may conflate human capital accumulation, a relative resource, ideology, values, a component of social class or simply a life course transition experience. We obviously can not separate these factors entirely, but by including variables intended to capture e.g. class differences and ideology, we can at least come closer to the real picture. Similar to age and cohabitation status, income does not have any explanatory power for any of the dependent variables. ${ }^{6}$ Income and education may of course be a sign of other factors than just relative resources (e.g. class-based attitudes). We therefore repeated the regressions while excluding the education variables, but again arrived at the same result. One might also expect there to be an urban/rural division with gender equality norms being stronger in urban areas as suggested by Ellingsæter (1998). However, we do not find any significant effect of living in the capital city. Contrary to previous literature the marginal effect of having children is insignificant, and this is also the case for 
the time availability variables ( $\underline{\text { Fulltime }}$ and $\underline{\text { Parttime })}$. As presented in the introduction, previous research has found that having children (Bernhardt et al. 2008; Ellingsæter 1998) and not working full time (Bernhardt et al. 2008) each affects peoples' attitudes towards gender equality negatively.

Ellingsæter's (1998) results suggest that men and women who work in different sectors to some extent have differing ideals regarding who should be the main breadwinner for the family. The most equality-oriented people are highly educated women working in genderneutral occupations (doctors and journalists), men in female-dominated occupations (nurses), and men working as journalists. We use the variable Public to get a crude measure of whether a respondent works in a female- or male-dominated sector, and find that working in the public sector is not of importance for any of the three dependent variables. The marginal effect of being religious is only significant for the gender equality variable, where it seems like religious people feel that gender equality is less important. That this variable is not statistically significantly correlated with our two other dependent variables (Sharing and Intervention) indicates that religiosity is only important for general attitudes towards gender equality and not for attitudes towards sharing household responsibilities or government intervention in family life. This, combined with the result in Knudsen and Wærness (2001) that being religious is negatively correlated with supporting mothers' employment, may indicate a special effect of religiosity on people's views on women's employment. Our political variables show that being to the right is negatively correlated with all three dependent variables while being to the left is instead positively correlated with all three dependent variables. The political variables can be seen as problematic since you might perceive yourself as left (right) if you want more (less) equality between the genders or more (less) government intervention, i.e. these variables may be endogenous, and endogenous variables may bias the coefficients of all other variables. However, our results regarding the other variables do not change when excluding the political variables from the regressions, and the potential problem therefore does not seem to be a severe concern in the present study. ${ }^{7}$

Living in Norway has a statistically significant and negative correlation with thinking that gender equality is important; is not statistically significantly correlated with views on sharing 
household responsibilities; and has a statistically significant and positive correlation with views on government intervention. This indicates that Swedes tend to feel that gender equality is more important than Norwegians (still, both groups feel it is important - the average answer is 8.475 and 8.838 for Norwegians and Swedes respectively). It should be noted that although the difference between the countries is statistically significant, the 'practical' significance can be questioned. That is, while living in Norway implies responses to the gender equality question that on average are 0.3 less (on a variable ranging from 0 to 10), it is far from obvious that this difference should be deemed important. Furthermore, by running ordered logit regressions (see Table 3 for the marginal effects of Norway dummy), we see that the result is driven solely by a lower probability of Norwegians answering 10 . We also see that the result regarding sharing of household responsibilities is insignificant for all values in the ordered logit results. Norwegians seem more enthusiastic than Swedes about government intervention to increase egalitarian sharing. This result can be deemed to be of more practical importance since living in Norway implies an average 1.4 higher response to the government intervention question. Looking at the results from the ordered logit regressions in Table 3, we also see that the likelihood that Norwegians respond with low numbers is lower than for Swedes and that Norwegians are more likely to respond with high numbers. This contests results from previous studies that claim that Swedes are more affirmative of gender equality. This will be discussed further in Section 4.

[Table 3]

\section{A closer look at the country differences}

Since the Norway dummy in the pooled regressions indicates significant differences between Norway and Sweden even after controlling for other relevant factors, and since the countries differ on several important variables (see Table 1), it is motivated to conduct sample splits. Taking a closer look at the different weights of each explanatory variable by running separate regressions (Table 4), we can see that the negative marginal effect of being male is considerably larger in Norway than in Sweden for the Gendereq variable, and this difference is statistically significant at the $5 \%$ level. ${ }^{8}$ The difference is not statistically significant for the other two dependent variables. 
[Table 4]

High income has a positive effect in Sweden for the Gendereq variable, although the difference between the countries is not statistically significant when explicitly tested.' Religion is negatively associated with Gendereq and Intervention in Norway only, but a test of the differences shows that they are not statistically significant. Regarding government intervention to foster gender equality in the household, there are statistically significant differences between Norway and Sweden if we look at higher education and being left wing. In Sweden, higher education is more positively correlated and being left wing is less positively correlated with Intervention..$^{10}$ Thus, in general, the same explanatory variables seem to be important in both countries.

As we noted in the first regressions, the Norway dummy is significant for two of the dependent variables (Gendereq and Intervention), even when controlling for other relevant factors. ${ }^{11}$ Furthermore, in general there seem to be the same underlying individual level explanatory variables at work in the two countries. It may be that the reason for the country difference lies at the macro level. Many scholars argue that macro-level mechanisms are important for explaining differences in the sharing of housework (Batalova and Cohen 2002; Fuwa 2004; Fuwa and Cohen 2007; Knudsen and Wærness 2008). The factors in focus are often cultural paradigms, the gender wage gap, the level of female employment and female political power. ${ }^{12}$

Investigating elite groups' explanations for why societal top positions are dominated by men, Teigen and Wängnerud (2009) find that Norwegians are more prone to use liberal feminist explanations, while Swedes more often use radical feminist explanations. Based on this they assume that the general gender equality discourses in the two countries differ accordingly (which seems plausible according to studies on specific policy areas, e.g., Jakobsson and Kotsadam 2009 on prostitution). Also Langvasbråten (2008) finds clear gender discourse differences between the countries when studying governmental action plans for gender equality and how multiculturalism is incorporated into these. This clear difference in gender equality discourse could possibly explain differences in attitudes towards different aspects of gender equality. 
Ellingsæter (1998) compares the Scandinavian countries and their attitudes towards gender equality. She adds the history of urbanisation, industrialisation and demographic transition as other important macro-level factors, and claims that urbanisation was faster in Sweden than in Norway, partly due to the fact that Sweden was the leading Scandinavian industrial country. The Swedish industrialisation, combined with a geographically clustered working class, led to a strong labour movement and finally a social-democratic hegemony that is argued to have affected values in a progressive way. The demographic transition also occurred later in Norway than in Sweden, a fact that Ellingsæter (1998) sees as an indication of a slower transition to a modern society. These factors are thought to affect values today, for example in that Norwegians are more religious and less prone to support gender equality. She also looks at the historical differences in policy efforts (cf. Hook 2006). Sweden had an expansion of the welfare state, including expansion of childcare services, before Norway, and women's employment was integrated into the policy agenda earlier. Whereas the post-war era in Sweden was characterised by emancipatory policy goals, it was a time of housewife ideology' in Norway. These types of macro explanations are not testable in our data and as Knudsen and Wærness (2008) point out, a problem with examining different structural forces is that they are interwoven, making them hard to separate analytically and empirically. The explanations do seem reasonable in terms of general gender equality though, and have been uncontested in the literature. However, our finding that the direction is reversed for the government intervention variable shows that the relationship may be quite complex. A modest interpretation would be that the result pointing to a weaker support for gender equality in Norway is less robust than previously thought, since the direction of the difference changes with the question asked. Another interpretation may be that Norwegians think that the government should be active in order to foster gender equality to a larger extent than Swedes simply because they do not feel that the right level has been reached. Two things should be remembered here: Norwegians do think gender equality is very important (be reminded that they are being compared to Swedes, who think it is even more important) and Norwegians may perceive that there is less gender equality in society (as compared to their ideal level) than Swedes. Whatever the reason, feasibility of promoting both the first and the second gender revolution is indicated in Norway. The result regarding government intervention is probably not driven by a present lower level of intervention to 
promote gender equality in Norway. First, it should be noted that the policies in the two countries are very similar. For instance, the debates on parental leave have been similar, and both countries have reserved time for fathers (two months in Sweden and one in Norway). Norway has also decided on female quotas to ensure at least $40 \%$ in publicly appointed boards and committees, and corporate boards (Teigen and Wägngnerud 2009).

A final concern is that the difference between Norway and Sweden is driven more by attitudes towards government intervention than by attitudes towards gender equality. Using data from the International Social Survey Programme (ISSP), Svallfors (2003) studies attitudes towards welfare state responsibility in different welfare states, including Norway and Sweden. The eight included questions concern whether it should be the government's responsibility to provide health care, to provide a decent standard of living for the unemployed, and to reduce income differences between rich and poor etc. Norwegians are found to think, more than the other studied countries, that these issues to a large extent are the responsibility of the state; France and Sweden place second and third. ${ }^{13}$ This result may indicate more interventionist attitudes in Norway in general, and it may be this rather than differences in gender equality attitudes that drives the result regarding Intervention. Unfortunately, we cannot separate the two issues since, as stated before, our question on government intervention includes two stimuli. However, in a study on attitudes towards prostitution in Norway and Sweden, Jakobsson and Kotsadam (2009) find that Swedes are more prone to want both buying and selling sex to be criminalised. Hence, it is not at all obvious that the result is driven by a general interventionist attitude in Norway, and even if that were the case, there would still be a larger political feasibility for active state policy to increase gender equality in Norway.

\section{Conclusion}

The entering of women into the public sphere (education, employment and politics) has been referred to as the first gender revolution. The second step is argued to occur when men take an equal responsibility for housework and caregiving in the private sphere. As former studies show, there has been a tendency towards a more egalitarian sharing of housework, although the differences are still large between the chores men and women perform. In 
Norway and Sweden, the current gender equality policies are very similar but, as we show, attitudes differ between the populations in some important respects.

Previous comparative research suggests that Swedes are more supportive of gender equality than Norwegians, and this is partly contested in this paper. Similar to previous research, we do find that Swedes are more positive towards gender equality in general (although the difference is small). However, we find no differences regarding views on egalitarian sharing of household responsibilities, and Norwegians are actually more supportive of government intervention aimed to increase gender equality at home. A modest interpretation would be that the result pointing to a weaker support for gender equality in Norway is less robust than previously thought, since the direction changes with the question asked. Another interpretation may be that Norwegians think that the government should be active in order to foster gender equality to a larger extent than Swedes.

Another important result is that the time availability variables (Fulltime and $\underline{\text { Parttime) }}$ ) and relative resources (partly captured via the income and education variables) are not very important for attitudes towards gender equality in this study. This is in contrast to previous findings, which suggest that they are indeed important for both actual sharing and values regarding sharing. Furthermore, respondent age is not significantly correlated with any of the dependent variables. This is an interesting result that contrasts the popular opinion in the debate on gender equality that things will change with new cohorts replacing old (and by assumption more conservative) ones. It also contrasts some previous empirical findings in the literature. Normatively, the lack of significant correlation between age and the dependent variables indicates the necessity of action since preferences for gender equality do not change automatically with the replacement of cohorts.

As we have seen in the present study, the questions chosen are of great importance for detecting differences between Norway and Sweden. That differences exist should be clear following our results, yet our main contribution is the indication that the differences are not as clear-cut as previously thought. Attitudes towards gender equality consist of a broad spectrum of issues, and it is not certain that the differences are similar over the whole spectrum. Moreover, attitudes may change and the different results compared to previous 
studies could be due to a narrowing of the differences between the countries over time. Further research is definitely warranted in this area to shed more light on these issues. In particular, our results suggest that differences between the countries hinge on the questions asked and further studies can more explicitly try to disentangle issues concerning the private and the public sphere, as well as liberal and radical feminist arguments. 


\section{References}

Batalova, J. and Cohen, P. (2002) 'Premarital Cohabitation and Housework: Couples in Cross-National Perspective', Journal of Marriage and the Family 64 (3): 743-755

Becker, G. S. (1991) A Treatise on the Family. Cambridge Harvard University Press.

Bernhardt, E., Noack T., and Hovde Lyngstad, T. (2008) 'Shared Housework in Norway and Sweden: Advancing the Gender Revolution', Journal of European Social Policy 18 (3): 275-288.

Coltrane, S. (2000) 'Research on Household Labor: Modeling and Measuring the Social Embeddedness of Routine Family Work', Journal of Marriage and Family 62 (4): 1208-1233.

Ellingsæter, A. L. (1998) 'Dual Breadwinner Societies: Provider Models in the Scandinavian Welfare States', Acta Sociologica 41 (1): 59-73.

Esping-Andersen, G. (1990) The Three Worlds of Welfare Capitalism. Cambridge: Polity.

Esping-Andersen, G. (1999) Social Foundations of Postindustrial Economies. New York: Oxford University Press.

Ferrarini, T. (2006) Families, States and Labour Markets : Institutions, Causes and Consequences of Family Policy in Post-War Welfare States. Cheltenham: Edward Elgar.

Fuwa, M. (2004) 'Macro-Level Gender Inequality and the Division of Household Labor in 22 Countries', American Sociological Review 69 (6): 751-767.

Fuwa, M. and Cohen, P. N. (2007) 'Housework and Social Policy.' Social Science Research 36 (2): 512-530.

Hook, J. L. (2006) 'Care in Context: Men's Unpaid Work in 20 Countries, 1965-2003', American Sociological Review 71 (4):639-660.

Jakobsson, N. and Kotsadam, A. (2009). 'What Explains Attitudes Toward Prostitution?', Working Paper no. 349, Department of Economics, University of Gothenburg.

Kautto, M., Fritzell, J., Hvinden, B., Kvist, J. and Uusitalo, H. (2001) 'Introduction: How

Different are the Nordic Welfare States?' in Kautto, M., Fritzell, J., Hvinden, B., Kvist, J. and

Uusitalo, H (eds) Nordic Welfare States in the European Context. London and New York:

Routledge.

Knudsen, K. and Wærness, K. (2001) 'National Context, Individual Characteristics and Attitudes on Mothers' Employment: A Comparative Analysis of Great Britain, Sweden and Norway', Acta Sociologica 44 (1): 67-79.

Langvasbråten, T. (2008) 'A Scandinavian Model? Gender Equality Discourses on Multiculturalism', Social Politics. International Studies in Gender, State \& Society 15 (1): 32-52.

Myrdal, G. (1968) Objektivitetsproblemet i Sambällsforskningen. Rabén \& Sjögren: Stockholm.

OECD Development Centre (2006). Gender, Institutions and Development Data Base (GID). Available online (20090218):

http://stats.oecd.org/WBOS/Index.aspx?DatasetCode=GID\&lang=en

Sjöberg, O. (2004) 'The Role of Family Policy Institutions in Explaining Gender-Role Attitudes: A Comparative Multilevel Analysis of Thirteen Industrialized Countries', Journal of European Social Policy 14 (2): 107-123.

Svallfors, S. (2003) 'Welfare Regimes and Welfare Opinions: A Comparison of Eight Western Countries', Social Indicators Research 64 (3): 495-520.

Svallfors, S. (2007) The Political Sociology of the Welfare State: Institutions, Social Cleavages, and Orientations, Studies in Social Inequality. Stanford: Stanford University Press.

Teigen, M. and Wägngnerud, L. (2009) 'Tracing Gender Equality Cultures: Elite Perceptions of Gender Equality in Norway and Sweden', Politics \& Gender 5: forthcoming.

Sunstein, C. (1997) Free Markets and Social Justice. Oxford: Oxford University Press. 


\section{Figures and tables}

Figure 1. Distribution of attitudes towards gender equality.

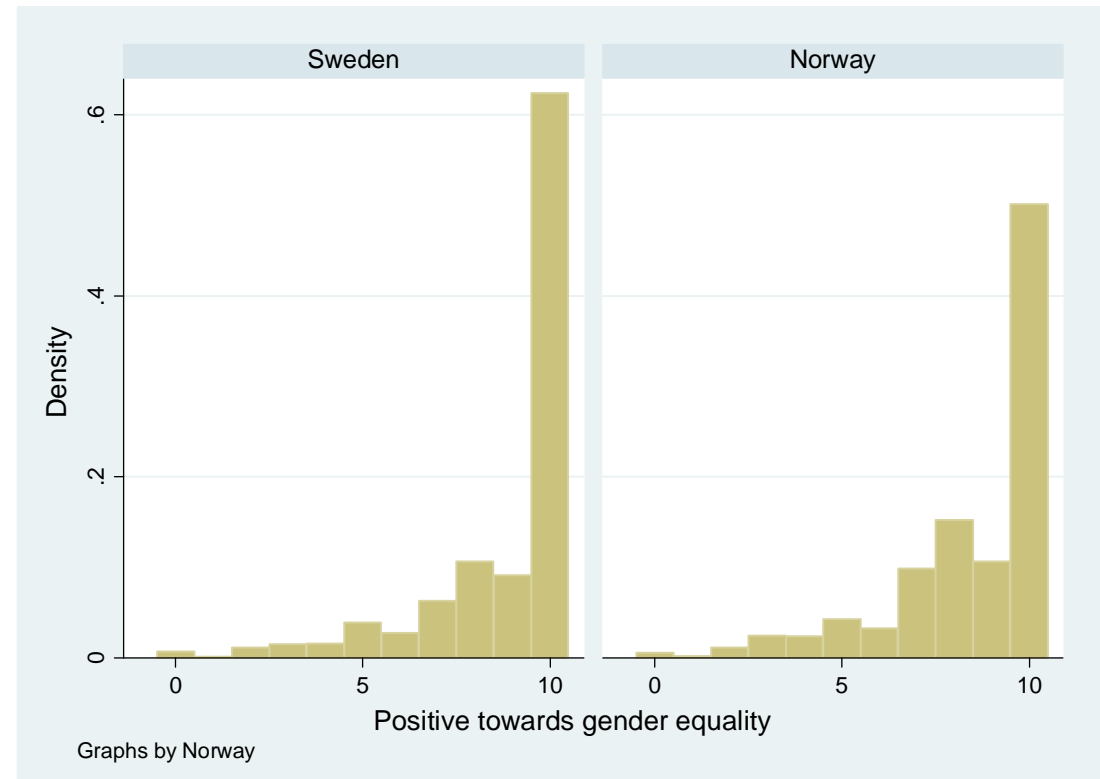

Attitudes towards gender equality are measured by answers to the question 'Do you think that gender equality is important?' ranging from 0 for 'No, not at all' to 10 for 'Yes, for sure'.

Figure 2. Distribution of attitudes towards sharing household responsibilities.

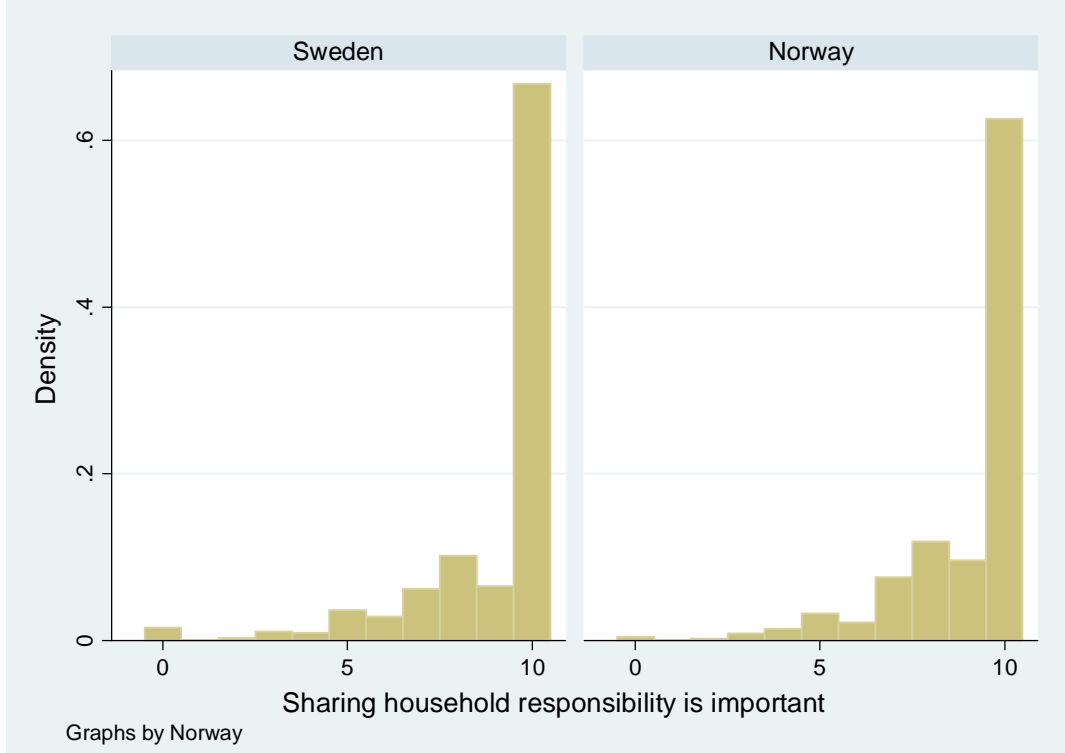

Attitudes towards sharing household responsibilities are measured by answers to the question 'Is it important that the man and the woman share the responsibility for the household?' ranging from 0 for 'No, not at all' to 10 for 'Yes, for sure'. 
Figure 3. Distribution of attitudes towards state intervention to increase gender equality.

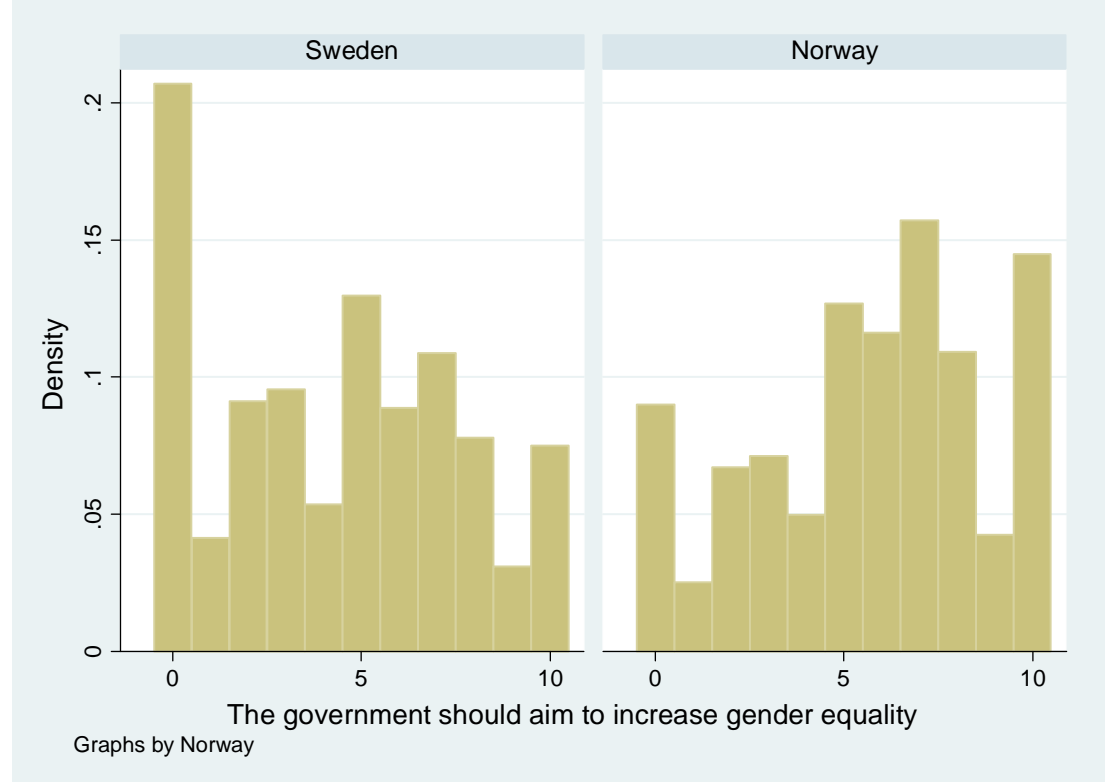

Attitudes towards gender equality are measured by answers to the question 'Do you think that the government should try to influence family life to increase gender equality, e.g. by subsidies or laws?' ranging from 0 for 'No, not at all' to 10 for 'Yes, for sure'. 
Table 1. Descriptive statistics.

\begin{tabular}{|c|c|c|c|c|c|c|c|c|}
\hline \multirow[b]{2}{*}{ Variable } & \multirow[b]{2}{*}{ Explanation } & \multicolumn{2}{|c|}{ Pooled sample } & \multicolumn{2}{|c|}{ Norway } & \multicolumn{2}{|c|}{ Sweden } & \multirow[b]{2}{*}{$\begin{array}{c}\text { Expected } \\
\text { effect }\end{array}$} \\
\hline & & Mean & St. Err & Mean & St. Err & Mean & St. Err & \\
\hline Gendereq & $\begin{array}{l}\text { Answer to the question 'Do you } \\
\text { think that gender equality is } \\
\text { important?' ranging from } 0 \text { for } \\
\text { 'No, not at all' to } 10 \text { for 'Yes, } \\
\text { for sure'. }\end{array}$ & 8.662 & 2.041 & 8.475 & 2.084 & 8.838 & 1.984 & \\
\hline Sharing & $\begin{array}{l}\text { Answer to the question 'Is it } \\
\text { important that the man and the } \\
\text { woman share the responsibility in the } \\
\text { bousebold?' ranging from } 0 \text { for } \\
\text { 'No, not at all' to } 10 \text { for 'Yes, } \\
\text { for sure'. }\end{array}$ & 8.961 & 1.842 & 8.981 & 1.707 & 8.943 & 1.962 & \\
\hline Intervention & $\begin{array}{l}\text { Answer to the question 'Do you } \\
\text { think that the government should try } \\
\text { to influence family life to increase } \\
\text { gender equality, e.g. by subsidies or } \\
\text { laws?' ranging from } 0 \text { for 'No, } \\
\text { not at all' to } 10 \text { for 'Yes, for } \\
\text { sure'. }\end{array}$ & 4.995 & 3.190 & 5.709 & 3.021 & 4.320 & 3.199 & \\
\hline Norway & $\begin{array}{l}=1 \text { if respondent lives in } \\
\text { Norway }\end{array}$ & 0.486 & 0.500 & & & & & $+/-$ \\
\hline Male & $=1$ if respondent is male & 0.475 & 0.499 & 0.445 & 0.497 & 0.503 & 0.500 & - \\
\hline Age & $=$ Respondent's age & 39.410 & 14.060 & 37.137 & 13.790 & 41.558 & 13.978 & - \\
\hline $\mathrm{Age}^{2}$ & $=$ Age $*$ Age & 1750.734 & 1139.937 & 1569.198 & 1084.796 & 1922.368 & 1164.262 & $+/-$ \\
\hline Child & $\begin{array}{l}=1 \text { if respondent has at least } \\
\text { one child }\end{array}$ & 0.318 & 0.466 & 0.331 & 0.471 & 0.306 & 0.461 & - \\
\hline Cohabit & $\begin{array}{l}=1 \text { if respondent is married or } \\
\text { cohabiting }\end{array}$ & 0.658 & 0.475 & 0.651 & 0.477 & 0.664 & 0.472 & - \\
\hline Highed & $\begin{array}{l}=1 \text { if respondent has at least } \\
\text { some university education }\end{array}$ & 0.460 & 0.498 & 0.488 & 0.500 & 0.434 & 0.496 & + \\
\hline Lowed & $\begin{array}{l}=1 \text { if respondent only has } \\
\text { elementary education or less }\end{array}$ & 0.133 & 0.340 & 0.098 & 0.298 & 0.167 & 0.373 & - \\
\hline Highinc & $\begin{array}{l}=1 \text { if respondent earns }>45000 \\
\text { SEK per month, or }>600000 \\
\text { NOK per year }\end{array}$ & 0.052 & 0.221 & 0.075 & 0.263 & 0.031 & 0.173 & + \\
\hline Lowinc & $\begin{array}{l}=1 \text { if respondent earns }<20000 \\
\text { SEK per month, or }<200000 \\
\text { NOK per year }\end{array}$ & 0.333 & 0.471 & 0.260 & 0.439 & 0.399 & 0.490 & - \\
\hline Capital & $\begin{array}{l}=1 \text { if respondent lives in the } \\
\text { capital city }\end{array}$ & 0.165 & 0.371 & 0.112 & 0.316 & 0.214 & 0.410 & + \\
\hline Fulltime & $\begin{array}{l}=1 \text { if respondent works full } \\
\text { time }\end{array}$ & 0.599 & 0.490 & 0.576 & 0.494 & 0.621 & 0.485 & + \\
\hline Parttime & $\begin{array}{l}=1 \text { if respondent works part } \\
\text { time }\end{array}$ & 0.112 & 0.316 & 0.108 & 0.310 & 0.116 & 0.321 & - \\
\hline Public & $\begin{array}{l}=1 \text { if respondent works in the } \\
\text { public sector }\end{array}$ & 0.362 & 0.481 & 0.347 & 0.476 & 0.381 & 0.486 & + \\
\hline Religious & $\begin{array}{l}=1 \text { if respondent participates in } \\
\text { religious activities at least once a } \\
\text { month. }\end{array}$ & 0.088 & 0.283 & 0.096 & 0.295 & 0.079 & 0.270 & - \\
\hline Right & $\begin{array}{l}=1 \text { if respondent answered } 8-10 \\
\text { on a } 0-10 \text { scale, where } 0 \\
\text { indicates that the respondent is } \\
\text { to the left politically and } 10 \text { that } \\
\text { he/she is to the right. }\end{array}$ & 0.174 & 0.379 & 0.174 & 0.378 & 0.175 & 0.380 & - \\
\hline Left & $\begin{array}{l}=1 \text { if respondent answered } 0-2 \\
\text { on a } 0-10 \text { scale, where } 0 \\
\text { indicates that the respondent is } \\
\text { to the left politically and } 10 \text { that } \\
\text { he/she is to the right. }\end{array}$ & 0.149 & 0.356 & 0.121 & 0.327 & 0.176 & 0.380 & + \\
\hline
\end{tabular}


Table 2. OLS regressions, pooled sample, Gendereq, Sharing, and Intervention are dependent variables.

\begin{tabular}{|c|c|c|c|}
\hline & $\begin{array}{l}(1) \\
\text { Gendereq }\end{array}$ & $\begin{array}{l}\text { (2) } \\
\text { Sharing }\end{array}$ & $\begin{array}{l}\text { (3) } \\
\text { Intervention }\end{array}$ \\
\hline \multirow[t]{2}{*}{ Norway } & $-0.314 * * *$ & 0.031 & $1.381 * * *$ \\
\hline & $(0.088)$ & $(0.078)$ & $(0.136)$ \\
\hline \multirow[t]{2}{*}{ Male } & $-0.555^{* * *}$ & $-0.410 * * *$ & $-0.681 * * *$ \\
\hline & $(0.081)$ & $(0.071)$ & $(0.124)$ \\
\hline \multirow[t]{2}{*}{ Age } & -0.030 & 0.007 & -0.035 \\
\hline & (0.023) & (0.021) & $(0.036)$ \\
\hline \multirow[t]{2}{*}{ Age2 } & 0.000 & 0.000 & 0.000 \\
\hline & $(0.000)$ & $(0.000)$ & $(0.000)$ \\
\hline \multirow[t]{2}{*}{ Cohabit } & -0.075 & -0.092 & -0.155 \\
\hline & $(0.089)$ & $(0.079)$ & $(0.137)$ \\
\hline \multirow[t]{2}{*}{ Highed } & $0.339 * * *$ & $0.137 *$ & $0.645^{* * *}$ \\
\hline & $(0.082)$ & $(0.072)$ & $(0.126)$ \\
\hline \multirow[t]{2}{*}{ Lowed } & 0.132 & 0.121 & -0.217 \\
\hline & $(0.136)$ & $(0.121)$ & $(0.210)$ \\
\hline \multirow[t]{2}{*}{ Highinc } & 0.097 & -0.067 & 0.089 \\
\hline & (0.164) & (0.145) & $(0.253)$ \\
\hline \multirow[t]{2}{*}{ Lowinc } & -0.028 & -0.010 & 0.062 \\
\hline & $(0.113)$ & $(0.100)$ & $(0.175)$ \\
\hline \multirow[t]{2}{*}{ Capital } & 0.081 & -0.016 & 0.128 \\
\hline & (0.105) & (0.093) & $(0.162)$ \\
\hline \multirow[t]{2}{*}{ Child } & -0.102 & -0.026 & -0.141 \\
\hline & (0.091) & $(0.080)$ & $(0.140)$ \\
\hline \multirow[t]{2}{*}{ Fulltime } & 0.095 & 0.020 & 0.073 \\
\hline & (0.141) & $(0.125)$ & $(0.218)$ \\
\hline \multirow[t]{2}{*}{ Parttime } & 0.015 & -0.011 & 0.052 \\
\hline & $(0.159)$ & (0.141) & $(0.245)$ \\
\hline \multirow[t]{2}{*}{ Public } & -0.003 & 0.046 & 0.170 \\
\hline & $(0.083)$ & $(0.074)$ & $(0.129)$ \\
\hline \multirow[t]{2}{*}{ Religious } & $-0.348^{* * *}$ & -0.025 & -0.294 \\
\hline & $(0.132)$ & $(0.116)$ & $(0.203)$ \\
\hline \multirow[t]{2}{*}{ Right } & $-0.369 * * *$ & $-0.331 * * *$ & $-1.219^{* * *}$ \\
\hline & $(0.099)$ & $(0.088)$ & $(0.153)$ \\
\hline \multirow[t]{2}{*}{ Left } & $0.576^{* * *}$ & $0.333 * * *$ & $1.040 * * *$ \\
\hline & $(0.107)$ & $(0.095)$ & $(0.166)$ \\
\hline \multirow[t]{2}{*}{ Constant } & $9.337 * * *$ & $8.832 * * *$ & $5.206 * * *$ \\
\hline & $(0.462)$ & $(0.409)$ & $(0.711)$ \\
\hline Observations & 2778 & 2774 & 2774 \\
\hline$\underline{\mathrm{R} \text {-squared }}$ & 0.06 & 0.04 & 0.13 \\
\hline
\end{tabular}


Table 3. Marginal effects for Norway after ordered logit.

\begin{tabular}{llll} 
& $(1)$ & $(2)$ & $(3)$ \\
Outcome & Gendereq & Sharing & Intervention \\
\hline 0 & $0.001^{* * *}$ & 0.001 & $-0.090^{* * *}$ \\
& $(0.001)$ & $(0.001)$ & $(0.010)$ \\
1 & $0.000^{*}$ & 0.000 & $-0.018^{* * *}$ \\
& $(0.000)$ & $(0.000)$ & $(0.003)$ \\
2 & $0.003^{* * *}$ & 0.000 & $-0.036^{* * *}$ \\
& $(0.001)$ & $(0.000)$ & $(0.004)$ \\
3 & $0.006^{* * *}$ & 0.001 & $-0.028^{* * *}$ \\
& $(0.002)$ & $(0.001)$ & $(0.003)$ \\
4 & $0.007 * * *$ & 0.001 & $-0.011^{* * *}$ \\
& $(0.00176)$ & $(0.001)$ & $(0.002)$ \\
5 & $0.012^{* * *}$ & 0.003 & $-0.007 * * *$ \\
& $(0.003)$ & $(0.002)$ & $(0.002)$ \\
6 & $0.010^{* * *}$ & 0.002 & $0.015^{* * *}$ \\
& $(0.002)$ & $(0.002)$ & $(0.002)$ \\
7 & $0.022^{* * *}$ & 0.006 & $0.045^{* * *}$ \\
& $(0.005)$ & $(0.005)$ & $(0.005)$ \\
8 & $0.025^{* * *}$ & 0.007 & $0.044^{* * *}$ \\
& $(0.006)$ & $(0.006)$ & $(0.005)$ \\
9 & $0.009^{* * *}$ & 0.004 & $0.021^{* * *}$ \\
& $(0.002)$ & $(0.003)$ & $(0.003)$ \\
10 & $-0.097 * * *$ & -0.025 & $0.070^{* * *}$ \\
& $(0.021)$ & $(0.021)$ & $(0.007)$ \\
\hline
\end{tabular}

Standard errors in parentheses.

* significant at $10 \%$; ** significant at $5 \%$; *** significant at $1 \%$. 
Table 4. OLS regressions, Norway and Sweden separated, Gendereq, Sharing and Intervention are dependent variables.
(1)
(2)
(3)
(4)
(5)
(6) Norway Sweden Norway Sweden Norway Sweden

\begin{tabular}{|c|c|c|c|c|c|c|}
\hline \multirow[b]{2}{*}{ Male } & \multicolumn{2}{|c|}{ Gendereq } & \multicolumn{2}{|c|}{ Sharing } & \multicolumn{2}{|c|}{ Intervention } \\
\hline & $\begin{array}{l}-0.732 * * * \\
(0.114)\end{array}$ & $\begin{array}{l}-0.315^{* * *} \\
(0.115)\end{array}$ & $\begin{array}{l}-0.466^{* * *} \\
(0.095)\end{array}$ & $\begin{array}{l}-0.291 \text { *** } \\
(0.110)\end{array}$ & $\begin{array}{l}-0.717 * * * \\
(0.166)\end{array}$ & $\begin{array}{l}-0.565^{* * * *} \\
(0.190)\end{array}$ \\
\hline Age & $\begin{array}{l}-0.017 \\
(0.031)\end{array}$ & $\begin{array}{l}-0.029 \\
(0.039)\end{array}$ & $\begin{array}{l}0.021 \\
(0.026)\end{array}$ & $\begin{array}{l}0.018 \\
(0.038)\end{array}$ & $\begin{array}{l}0.006 \\
(0.046)\end{array}$ & $\begin{array}{l}-0.090 \\
(0.065)\end{array}$ \\
\hline Age2 & $\begin{array}{l}0.000 \\
(0.000)\end{array}$ & $\begin{array}{l}0.000 \\
(0.000)\end{array}$ & $\begin{array}{l}-0.000 \\
(0.000)\end{array}$ & $\begin{array}{l}0.000 \\
(0.000)\end{array}$ & $\begin{array}{l}-0.000 \\
(0.001)\end{array}$ & $\begin{array}{l}0.001 \\
(0.001)\end{array}$ \\
\hline Cohabit & $\begin{array}{l}-0.187 \\
(0.123)\end{array}$ & $\begin{array}{l}0.059 \\
(0.129)\end{array}$ & $\begin{array}{l}-0.079 \\
(0.102)\end{array}$ & $\begin{array}{l}-0.119 \\
(0.123)\end{array}$ & $\begin{array}{l}-0.086 \\
(0.178)\end{array}$ & $\begin{array}{l}-0.284 \\
(0.213)\end{array}$ \\
\hline Highed & $\begin{array}{l}0.234^{* *} \\
(0.113)\end{array}$ & $\begin{array}{l}0.467 * * * \\
(0.119)\end{array}$ & $\begin{array}{l}0.102 \\
(0.094)\end{array}$ & $\begin{array}{l}0.174 \\
(0.114)\end{array}$ & $\begin{array}{l}0.395^{* *} \\
(0.164)\end{array}$ & $\begin{array}{l}0.936 * * * \\
(0.197)\end{array}$ \\
\hline Lowed & $\begin{array}{l}0.191 \\
(0.201)\end{array}$ & $\begin{array}{l}0.101 \\
(0.190)\end{array}$ & $\begin{array}{l}-0.067 \\
(0.167)\end{array}$ & $\begin{array}{l}0.193 \\
(0.181)\end{array}$ & $\begin{array}{l}0.029 \\
(0.292)\end{array}$ & $\begin{array}{l}-0.395 \\
(0.314)\end{array}$ \\
\hline Highinc & $\begin{array}{l}-0.080 \\
(0.207)\end{array}$ & $\begin{array}{l}0.579 * * \\
(0.280)\end{array}$ & $\begin{array}{l}-0.039 \\
(0.172)\end{array}$ & $\begin{array}{l}-0.008 \\
(0.268)\end{array}$ & $\begin{array}{l}-0.224 \\
(0.300)\end{array}$ & $\begin{array}{l}0.820^{*} \\
(0.463)\end{array}$ \\
\hline Lowinc & $\begin{array}{l}-0.079 \\
(0.186)\end{array}$ & $\begin{array}{l}0.096 \\
(0.143)\end{array}$ & $\begin{array}{l}-0.146 \\
(0.154)\end{array}$ & $\begin{array}{l}0.129 \\
(0.137)\end{array}$ & $\begin{array}{l}-0.199 \\
(0.271)\end{array}$ & $\begin{array}{l}0.309 \\
(0.237)\end{array}$ \\
\hline Capital & $\begin{array}{l}0.008 \\
(0.174)\end{array}$ & $\begin{array}{l}0.123 \\
(0.131)\end{array}$ & $\begin{array}{l}0.051 \\
(0.145)\end{array}$ & $\begin{array}{l}-0.103 \\
(0.126)\end{array}$ & $\begin{array}{l}0.108 \\
(0.253)\end{array}$ & $\begin{array}{l}0.134 \\
(0.218)\end{array}$ \\
\hline Child & $\begin{array}{l}-0.155 \\
(0.131)\end{array}$ & $\begin{array}{l}-0.091 \\
(0.126)\end{array}$ & $\begin{array}{l}-0.003 \\
(0.109)\end{array}$ & $\begin{array}{l}-0.080 \\
(0.121)\end{array}$ & $\begin{array}{l}-0.006 \\
(0.191)\end{array}$ & $\begin{array}{l}-0.304 \\
(0.209)\end{array}$ \\
\hline Fulltime & $\begin{array}{l}0.132 \\
(0.171)\end{array}$ & $\begin{array}{l}0.162 \\
(0.162)\end{array}$ & $\begin{array}{l}-0.107 \\
(0.142)\end{array}$ & $\begin{array}{l}0.190 \\
(0.155)\end{array}$ & $\begin{array}{l}-0.144 \\
(0.250)\end{array}$ & $\begin{array}{l}0.209 \\
(0.268)\end{array}$ \\
\hline Parttime & $\begin{array}{l}0.166 \\
(0.209)\end{array}$ & $\begin{array}{l}0.000 \\
(0.000)\end{array}$ & $\begin{array}{l}0.044 \\
(0.174)\end{array}$ & $\begin{array}{l}0.000 \\
(0.000)\end{array}$ & $\begin{array}{l}0.025 \\
(0.305)\end{array}$ & $\begin{array}{l}0.000 \\
(0.000)\end{array}$ \\
\hline Public & $\begin{array}{l}-0.053 \\
(0.119)\end{array}$ & $\begin{array}{l}0.055 \\
(0.117)\end{array}$ & $\begin{array}{l}0.048 \\
(0.099)\end{array}$ & $\begin{array}{l}0.019 \\
(0.112)\end{array}$ & $\begin{array}{l}0.163 \\
(0.173)\end{array}$ & $\begin{array}{l}0.170 \\
(0.193)\end{array}$ \\
\hline Religious & $\begin{array}{l}-0.501^{* * *} \\
(0.176)\end{array}$ & $\begin{array}{l}-0.142 \\
(0.198)\end{array}$ & $\begin{array}{l}0.001 \\
(0.147)\end{array}$ & $\begin{array}{l}-0.081 \\
(0.189)\end{array}$ & $\begin{array}{l}-0.538^{* *} \\
(0.256)\end{array}$ & $\begin{array}{l}0.049 \\
(0.327)\end{array}$ \\
\hline Right & $\begin{array}{l}-0.380^{* * *} \\
(0.140)\end{array}$ & $\begin{array}{l}-0.341 * * \\
(0.140)\end{array}$ & $\begin{array}{l}-0.438^{* * *} \\
(0.117)\end{array}$ & $\begin{array}{l}-0.185 \\
(0.134)\end{array}$ & $\begin{array}{l}-1.107^{* * *} \\
(0.204)\end{array}$ & $\begin{array}{l}-1.367 * * * \\
(0.232)\end{array}$ \\
\hline Left & $\begin{array}{l}0.778^{* * *} \\
(0.161)\end{array}$ & $\begin{array}{l}0.431 * * * \\
(0.143)\end{array}$ & $\begin{array}{l}0.365^{* * *} \\
(0.134)\end{array}$ & $\begin{array}{l}0.330^{* *} \\
(0.136)\end{array}$ & $\begin{array}{l}1.403^{* * * *} \\
(0.234)\end{array}$ & $\begin{array}{l}0.743 * * * \\
(0.236)\end{array}$ \\
\hline Constant & $\begin{array}{l}8.994 * * * \\
(0.584)\end{array}$ & $\begin{array}{l}8.859 * * * \\
(0.841)\end{array}$ & $\begin{array}{l}8.904 * * * \\
(0.486)\end{array}$ & $\begin{array}{l}8.157 * * * \\
(0.803)\end{array}$ & $\begin{array}{l}6.127 * * * \\
(0.849)\end{array}$ & $\begin{array}{l}6.064 * * * \\
(1.389)\end{array}$ \\
\hline $\begin{array}{l}\text { Observations } \\
\text { R-squared }\end{array}$ & $\begin{array}{l}1508 \\
0.07\end{array}$ & $\begin{array}{l}1270 \\
0.05\end{array}$ & $\begin{array}{l}1507 \\
0.05\end{array}$ & $\begin{array}{l}1267 \\
0.04\end{array}$ & $\begin{array}{l}1506 \\
0.09\end{array}$ & $\begin{array}{l}1268 \\
0.09\end{array}$ \\
\hline
\end{tabular}

Standard errors in parentheses.

* significant at $10 \%$; ** significant at $5 \%$; *** significant at $1 \%$. 


\section{Appendix}

Table A1: OLS regressions, pooled sample, Gendereq, dependent variable, successive introduction of independent variables

\begin{tabular}{|c|c|c|c|c|c|c|c|c|}
\hline & (1) & (2) & (3) & (4) & (5) & (6) & (7) & (8) \\
\hline Norway & $\begin{array}{l}-0.362^{* * *} \\
(0.068)\end{array}$ & $\begin{array}{l}-0.391 * * * \\
(0.076)\end{array}$ & $\begin{array}{l}-0.376^{* * *} \\
(0.076)\end{array}$ & $\begin{array}{l}-0.379 * * * \\
(0.076)\end{array}$ & $\begin{array}{l}-0.366 \text { *** } \\
(0.077)\end{array}$ & $\begin{array}{l}-0.366 \text { *** } \\
(0.078)\end{array}$ & $\begin{array}{l}-0.334 * * * \\
(0.088)\end{array}$ & $\begin{array}{l}-0.314 * * * \\
(0.088)\end{array}$ \\
\hline Male & & $\begin{array}{l}-0.594 * * * \\
(0.073)\end{array}$ & $\begin{array}{l}-0.587^{* * *} \\
(0.073)\end{array}$ & $\begin{array}{l}-0.577^{* * *} \\
(0.074)\end{array}$ & $\begin{array}{l}-0.584 * * * \\
(0.074)\end{array}$ & $\begin{array}{l}-0.584 * * * \\
(0.075)\end{array}$ & $\begin{array}{l}-0.567 * * * \\
(0.081)\end{array}$ & $\begin{array}{l}-0.555^{\text {**** }} \\
(0.081)\end{array}$ \\
\hline Age & & $\begin{array}{l}-0.057^{* * *} \\
(0.019)\end{array}$ & $\begin{array}{l}-0.057^{* * *} \\
(0.019)\end{array}$ & $\begin{array}{l}-0.045^{* *} \\
(0.021)\end{array}$ & $\begin{array}{l}-0.049 * * \\
(0.022)\end{array}$ & $\begin{array}{l}-0.049 * * \\
(0.022)\end{array}$ & $\begin{array}{l}-0.028 \\
(0.024)\end{array}$ & $\begin{array}{l}-0.030 \\
(0.023)\end{array}$ \\
\hline Age2 & & $\begin{array}{l}0.001 * * * \\
(0.000)\end{array}$ & $\begin{array}{l}0.001 * * * \\
(0.000)\end{array}$ & $\begin{array}{l}0.001^{* *} \\
(0.000)\end{array}$ & $\begin{array}{l}0.001 * * \\
(0.000)\end{array}$ & $\begin{array}{l}0.001^{* *} \\
(0.000)\end{array}$ & $\begin{array}{l}0.000 \\
(0.000)\end{array}$ & $\begin{array}{l}0.000 \\
(0.000)\end{array}$ \\
\hline Cohabit & & $\begin{array}{l}-0.064 \\
(0.081)\end{array}$ & $\begin{array}{l}-0.060 \\
(0.081)\end{array}$ & $\begin{array}{l}-0.044 \\
(0.084)\end{array}$ & $\begin{array}{l}-0.047 \\
(0.084)\end{array}$ & $\begin{array}{l}-0.047 \\
(0.084)\end{array}$ & $\begin{array}{l}-0.101 \\
(0.089)\end{array}$ & $\begin{array}{l}-0.075 \\
(0.089)\end{array}$ \\
\hline Highed & & $\begin{array}{l}0.263^{* * *} \\
(0.077)\end{array}$ & $\begin{array}{l}0.291 * * * \\
(0.077)\end{array}$ & $\begin{array}{l}0.289^{* * *} \\
(0.078)\end{array}$ & $\begin{array}{l}0.287 * * * \\
(0.078)\end{array}$ & $\begin{array}{l}0.287 * * * \\
(0.078)\end{array}$ & $\begin{array}{l}0.351 * * * \\
(0.082)\end{array}$ & $\begin{array}{l}0.339 * * * \\
(0.082)\end{array}$ \\
\hline Lowed & & $\begin{array}{l}0.025 \\
(0.124)\end{array}$ & $\begin{array}{l}0.021 \\
(0.123)\end{array}$ & $\begin{array}{l}0.019 \\
(0.124)\end{array}$ & $\begin{array}{l}0.020 \\
(0.124)\end{array}$ & $\begin{array}{l}0.020 \\
(0.124)\end{array}$ & $\begin{array}{l}0.151 \\
(0.137)\end{array}$ & $\begin{array}{l}0.132 \\
(0.136)\end{array}$ \\
\hline Highinc & & $\begin{array}{l}0.010 \\
(0.164)\end{array}$ & $\begin{array}{l}0.028 \\
(0.164)\end{array}$ & $\begin{array}{l}0.025 \\
(0.164)\end{array}$ & $\begin{array}{l}0.017 \\
(0.164)\end{array}$ & $\begin{array}{l}0.017 \\
(0.164)\end{array}$ & $\begin{array}{l}-0.006 \\
(0.165)\end{array}$ & $\begin{array}{l}0.097 \\
(0.164)\end{array}$ \\
\hline Lowinc & & $\begin{array}{l}-0.087 \\
(0.093)\end{array}$ & $\begin{array}{l}-0.067 \\
(0.093)\end{array}$ & $\begin{array}{l}-0.074 \\
(0.093)\end{array}$ & $\begin{array}{l}-0.024 \\
(0.107)\end{array}$ & $\begin{array}{l}-0.023 \\
(0.108)\end{array}$ & $\begin{array}{l}0.055 \\
(0.113)\end{array}$ & $\begin{array}{l}-0.028 \\
(0.113)\end{array}$ \\
\hline Capital & & $\begin{array}{l}0.116 \\
(0.099)\end{array}$ & $\begin{array}{l}0.104 \\
(0.098)\end{array}$ & $\begin{array}{l}0.085 \\
(0.099)\end{array}$ & $\begin{array}{l}0.086 \\
(0.099)\end{array}$ & $\begin{array}{l}0.087 \\
(0.099)\end{array}$ & $\begin{array}{l}0.054 \\
(0.106)\end{array}$ & $\begin{array}{l}0.081 \\
(0.105)\end{array}$ \\
\hline Religious & & & $\begin{array}{l}-0.376^{* * *} \\
(0.125)\end{array}$ & $\begin{array}{l}-0.380^{* * *} \\
(0.125)\end{array}$ & $\begin{array}{l}-0.379 * * * \\
(0.126)\end{array}$ & $\begin{array}{l}-0.379 * * * \\
(0.126)\end{array}$ & $\begin{array}{l}-0.389^{* * *} \\
(0.133)\end{array}$ & $\begin{array}{l}-0.348^{* * *} \\
(0.132)\end{array}$ \\
\hline Child & & & & $\begin{array}{l}-0.116 \\
(0.089)\end{array}$ & $\begin{array}{l}-0.112 \\
(0.089)\end{array}$ & $\begin{array}{l}-0.112 \\
(0.089)\end{array}$ & $\begin{array}{l}-0.102 \\
(0.091)\end{array}$ & $\begin{array}{l}-0.102 \\
(0.091)\end{array}$ \\
\hline Fulltime & & & & & $\begin{array}{l}0.092 \\
(0.096)\end{array}$ & $\begin{array}{l}0.096 \\
(0.112)\end{array}$ & $\begin{array}{l}0.093 \\
(0.142)\end{array}$ & $\begin{array}{l}0.095 \\
(0.141)\end{array}$ \\
\hline Parttime & & & & & & $\begin{array}{l}0.008 \\
(0.136)\end{array}$ & $\begin{array}{l}-0.018 \\
(0.160)\end{array}$ & $\begin{array}{l}0.015 \\
(0.159)\end{array}$ \\
\hline Public & & & & & & & $\begin{array}{l}0.064 \\
(0.083)\end{array}$ & $\begin{array}{l}-0.003 \\
(0.083)\end{array}$ \\
\hline Right & & & & & & & & $\begin{array}{l}-0.369^{* * *} \\
(0.099)\end{array}$ \\
\hline Left & & & & & & & & $\begin{array}{l}0.576^{* * *} \\
(0.107)\end{array}$ \\
\hline Constant & $\begin{array}{l}8.838^{* * *} \\
(0.048)\end{array}$ & $\begin{array}{l}10.013^{* * *} \\
(0.407)\end{array}$ & $\begin{array}{l}10.014 \text { *** } \\
(0.406)\end{array}$ & $\begin{array}{l}9.828^{* * *} \\
(0.430)\end{array}$ & $\begin{array}{l}9.821 * * * \\
(0.430)\end{array}$ & $\begin{array}{l}9.822 * * * \\
(0.430)\end{array}$ & $\begin{array}{l}9.308^{* * * *} \\
(0.465)\end{array}$ & $\begin{array}{l}9.337 * * * \\
(0.462)\end{array}$ \\
\hline Obs. & 3528 & 3164 & 3161 & 3129 & 3128 & 3128 & 2781 & 2778 \\
\hline R-squared & 0.01 & 0.04 & 0.04 & 0.04 & 0.04 & 0.04 & 0.04 & 0.06 \\
\hline
\end{tabular}

Standard errors in parentheses

* significant at $10 \%$; ** significant at $5 \%$; *** significant at $1 \%$ 
Table A2: OLS regressions, pooled sample, Share, dependent variable, successive introduction of independent variables

\begin{tabular}{|c|c|c|c|c|c|c|c|c|}
\hline & (1) & $(2)$ & (3) & (4) & (5) & (6) & $(7)$ & (8) \\
\hline \multirow[t]{2}{*}{ Norway } & 0.039 & 0.073 & 0.075 & 0.061 & 0.074 & 0.078 & 0.020 & 0.031 \\
\hline & $(0.062)$ & $(0.069)$ & $(0.069)$ & $(0.069)$ & $(0.070)$ & $(0.071)$ & $(0.078)$ & $(0.078)$ \\
\hline \multirow[t]{2}{*}{ Male } & & $-0.514 * * *$ & $-0.513^{* * *}$ & $-0.488^{* * *}$ & $-0.495^{* * *}$ & $-0.489 * * *$ & $-0.423 * * *$ & $-0.410 * * *$ \\
\hline & & $(0.067)$ & $(0.067)$ & $(0.067)$ & $(0.067)$ & $(0.068)$ & $(0.072)$ & $(0.071)$ \\
\hline \multirow[t]{2}{*}{ Age } & & 0.008 & 0.008 & 0.010 & 0.006 & 0.004 & 0.008 & 0.007 \\
\hline & & $(0.018)$ & $(0.018)$ & $(0.019)$ & $(0.020)$ & $(0.020)$ & $(0.021)$ & $(0.021)$ \\
\hline \multirow[t]{2}{*}{ Age2 } & & 0.000 & 0.000 & 0.000 & 0.000 & 0.000 & 0.000 & 0.000 \\
\hline & & $(0.000)$ & $(0.000)$ & $(0.000)$ & $(0.000)$ & $(0.000)$ & $(0.000)$ & $(0.000)$ \\
\hline \multirow[t]{2}{*}{ Cohabit } & & -0.096 & -0.093 & -0.105 & -0.106 & -0.108 & -0.112 & -0.092 \\
\hline & & $(0.074)$ & $(0.074)$ & $(0.077)$ & $(0.077)$ & $(0.077)$ & $(0.079)$ & $(0.079)$ \\
\hline \multirow[t]{2}{*}{ Highed } & & $0.159 * *$ & $0.169 * *$ & $0.164 * *$ & $0.161 * *$ & $0.163^{* *}$ & $0.143^{* *}$ & $0.137^{*}$ \\
\hline & & $(0.070)$ & $(0.071)$ & $(0.071)$ & $(0.071)$ & $(0.071)$ & $(0.073)$ & $(0.072)$ \\
\hline \multirow[t]{2}{*}{ Lowed } & & 0.129 & 0.128 & 0.108 & 0.109 & 0.110 & 0.133 & 0.121 \\
\hline & & $(0.113)$ & $(0.113)$ & $(0.113)$ & $(0.113)$ & $(0.113)$ & $(0.121)$ & $(0.121)$ \\
\hline \multirow[t]{2}{*}{ Highinc } & & -0.153 & -0.151 & -0.155 & -0.164 & -0.164 & -0.142 & -0.067 \\
\hline & & $(0.150)$ & $(0.150)$ & $(0.149)$ & $(0.149)$ & $(0.149)$ & $(0.146)$ & $(0.145)$ \\
\hline \multirow[t]{2}{*}{ Lowinc } & & -0.048 & -0.046 & -0.040 & 0.012 & 0.022 & 0.045 & -0.010 \\
\hline & & $(0.085)$ & $(0.085)$ & $(0.085)$ & $(0.097)$ & $(0.099)$ & $(0.100)$ & $(0.100)$ \\
\hline \multirow[t]{2}{*}{ Capital } & & 0.007 & 0.002 & -0.018 & -0.016 & -0.013 & -0.036 & -0.016 \\
\hline & & $(0.090)$ & $(0.090)$ & $(0.090)$ & $(0.090)$ & $(0.090)$ & $(0.094)$ & $(0.093)$ \\
\hline \multirow[t]{2}{*}{ Religious } & & & -0.061 & -0.056 & -0.055 & -0.055 & -0.053 & -0.025 \\
\hline & & & $(0.114)$ & $(0.114)$ & $(0.114)$ & $(0.114)$ & $(0.117)$ & $(0.116)$ \\
\hline \multirow[t]{2}{*}{ Child } & & & & -0.029 & -0.024 & -0.026 & -0.024 & -0.026 \\
\hline & & & & $(0.081)$ & $(0.081)$ & $(0.081)$ & $(0.081)$ & $(0.080)$ \\
\hline \multirow[t]{2}{*}{ Fulltime } & & & & & 0.095 & 0.130 & 0.019 & 0.020 \\
\hline & & & & & $(0.087)$ & $(0.102)$ & $(0.125)$ & $(0.125)$ \\
\hline \multirow[t]{2}{*}{ Parttime } & & & & & & 0.079 & -0.031 & -0.011 \\
\hline & & & & & & $(0.123)$ & $(0.141)$ & $(0.141)$ \\
\hline \multirow[t]{2}{*}{ Public } & & & & & & & 0.095 & 0.046 \\
\hline & & & & & & & $(0.074)$ & $(0.074)$ \\
\hline \multirow[t]{2}{*}{ Right } & & & & & & & & $-0.331 * * *$ \\
\hline & & & & & & & & $(0.088)$ \\
\hline \multirow[t]{2}{*}{ Left } & & & & & & & & $0.333^{* * *}$ \\
\hline & & & & & & & & $(0.095)$ \\
\hline \multirow[t]{2}{*}{ Constant } & $8.943 * * *$ & $8.770 * * *$ & $8.773 * * *$ & $8.759 * * *$ & $8.747 * * *$ & $8.758 * * *$ & $8.800 * * *$ & $8.832 * * *$ \\
\hline & $(0.043)$ & $(0.371)$ & $(0.371)$ & $(0.391)$ & $(0.391)$ & $(0.392)$ & $(0.410)$ & $(0.409)$ \\
\hline Obs. & 3522 & 3159 & 3156 & 3124 & 3123 & 3123 & 2777 & 2774 \\
\hline$\underline{\mathrm{R} \text {-squared }}$ & 0.00 & 0.03 & 0.03 & 0.03 & 0.03 & 0.03 & 0.02 & 0.04 \\
\hline
\end{tabular}

Standard errors in parentheses

* significant at $10 \%$; ** significant at 5\%; *** significant at $1 \%$ 
Table A3: OLS regressions, pooled sample, Intervention, dependent variable, successive introduction of independent variables

\begin{tabular}{|c|c|c|c|c|c|c|c|c|}
\hline & (1) & (2) & (3) & (4) & (5) & (6) & $(7)$ & (8) \\
\hline \multirow[t]{2}{*}{ Norway } & $1.389 * * *$ & $1.269 * * *$ & $1.279 * * *$ & $1.290^{* * *}$ & $1.302^{* * *}$ & $1.305^{* * *}$ & $1.342^{* * *}$ & $1.381 * * *$ \\
\hline & $(0.105)$ & $(0.118)$ & $(0.118)$ & $(0.118)$ & $(0.120)$ & $(0.121)$ & $(0.138)$ & $(0.136)$ \\
\hline \multirow[t]{2}{*}{ Male } & & $-0.872^{* * *}$ & $-0.870^{* * *}$ & $-0.856^{* * *}$ & $-0.863^{* * *}$ & -0.859 *** & $-0.734 * * *$ & $-0.681 * * *$ \\
\hline & & $(0.114)$ & $(0.114)$ & $(0.115)$ & $(0.115)$ & $(0.116)$ & $(0.127)$ & $(0.124)$ \\
\hline \multirow[t]{2}{*}{ Age } & & $-0.068^{* *}$ & $-0.068^{* *}$ & -0.051 & -0.055 & -0.057 & -0.032 & -0.035 \\
\hline & & $(0.030)$ & $(0.030)$ & (0.033) & (0.034) & $(0.035)$ & $(0.037)$ & $(0.036)$ \\
\hline \multirow[t]{2}{*}{ Age2 } & & $0.001 * *$ & $0.001 * *$ & 0.001 & 0.001 & 0.001 & 0.000 & 0.000 \\
\hline & & $(0.000)$ & $(0.000)$ & $(0.000)$ & $(0.000)$ & $(0.000)$ & $(0.000)$ & $(0.000)$ \\
\hline \multirow[t]{2}{*}{ Cohabit } & & $-0.217^{*}$ & $-0.218^{*}$ & -0.156 & -0.158 & -0.159 & -0.217 & -0.155 \\
\hline & & $(0.126)$ & $(0.126)$ & $(0.131)$ & $(0.131)$ & $(0.132)$ & $(0.140)$ & $(0.137)$ \\
\hline \multirow[t]{2}{*}{ Highed } & & $0.637^{* * *} *$ & $0.654 * * *$ & $0.657 * * *$ & $0.656^{* * *}$ & $0.657 * * *$ & $0.660 * * *$ & $0.645^{* * *}$ \\
\hline & & $(0.120)$ & $(0.120)$ & $(0.121)$ & $(0.121)$ & $(0.121)$ & $(0.129)$ & $(0.126)$ \\
\hline \multirow[t]{2}{*}{ Lowed } & & -0.237 & -0.242 & -0.249 & -0.248 & -0.247 & -0.179 & -0.217 \\
\hline & & (0.192) & (0.192) & (0.193) & (0.193) & (0.193) & $(0.214)$ & $(0.210)$ \\
\hline \multirow[t]{2}{*}{ Highinc } & & -0.176 & -0.181 & -0.180 & -0.187 & -0.187 & -0.169 & 0.089 \\
\hline & & $(0.254)$ & $(0.255)$ & $(0.255)$ & $(0.255)$ & $(0.255)$ & $(0.258)$ & $(0.253)$ \\
\hline \multirow[t]{2}{*}{ Lowinc } & & 0.087 & 0.104 & 0.097 & 0.145 & 0.151 & 0.237 & 0.062 \\
\hline & & $(0.144)$ & (0.144) & $(0.145)$ & $(0.167)$ & $(0.169)$ & $(0.177)$ & $(0.175)$ \\
\hline \multirow[t]{2}{*}{ Capital } & & 0.079 & 0.073 & 0.066 & 0.068 & 0.069 & 0.057 & 0.128 \\
\hline & & $(0.153)$ & (0.153) & (0.154) & (0.154) & (0.154) & $(0.166)$ & $(0.162)$ \\
\hline \multirow[t]{2}{*}{ Religious } & & & -0.320 & -0.309 & -0.309 & -0.308 & $-0.385^{*}$ & -0.294 \\
\hline & & & (0.195) & (0.195) & $(0.195)$ & (0.195) & $(0.207)$ & $(0.203)$ \\
\hline \multirow[t]{2}{*}{ Child } & & & & -0.186 & -0.181 & -0.182 & -0.140 & -0.141 \\
\hline & & & & (0.138) & (0.139) & (0.139) & (0.143) & $(0.140)$ \\
\hline \multirow[t]{2}{*}{ Fulltime } & & & & & 0.087 & 0.110 & 0.073 & 0.073 \\
\hline & & & & & (0.149) & (0.175) & $(0.223)$ & $(0.218)$ \\
\hline \multirow[t]{2}{*}{ Parttime } & & & & & & 0.053 & -0.008 & 0.052 \\
\hline & & & & & & (0.211) & $(0.250)$ & $(0.245)$ \\
\hline \multirow[t]{2}{*}{ Public } & & & & & & & $0.344^{* * *}$ & 0.170 \\
\hline & & & & & & & $(0.130)$ & $(0.129)$ \\
\hline \multirow[t]{2}{*}{ Right } & & & & & & & & $-1.219 * * *$ \\
\hline & & & & & & & & $(0.153)$ \\
\hline \multirow[t]{2}{*}{ Left } & & & & & & & & $1.040 * * *$ \\
\hline & & & & & & & & $(0.166)$ \\
\hline \multirow[t]{2}{*}{ Constant } & $4.320^{* * *}$ & $5.987 * * *$ & $5.988^{* * *}$ & $5.708 * * *$ & $5.701 * * *$ & $5.708^{* * *}$ & $5.064 * * *$ & $5.206^{* * *}$ \\
\hline & $(0.073)$ & $(0.631)$ & $(0.631)$ & $(0.669)$ & $(0.669)$ & $(0.670)$ & $(0.726)$ & $(0.711)$ \\
\hline Obs. & 3523 & 3160 & 3157 & 3125 & 3124 & 3124 & 2777 & 2774 \\
\hline R-squared & 0.05 & 0.08 & 0.08 & 0.08 & 0.08 & 0.08 & 0.09 & 0.13 \\
\hline
\end{tabular}

Standard errors in parentheses

* significant at $10 \%$; ** significant at $5 \%$; *** significant at $1 \%$ 
${ }^{1}$ Liberal feminism is centred on changing individual female behaviour to advance gender equality. Radical feminism instead focuses on that men dominate women, and that this power relation must be eliminated (Teigen and Wängnerud 2009).

2 The marginal effects after ordered logit concerning Norway are presented in Table 3, and the other results are available upon request.

3 These results are available upon request.

${ }^{4}$ The results from the stepwise regressions show that age is significant in the Gendereq regression until having children, working full time, part time, and in the public sector, is controlled for. For Intervention age is significant until having children is controlled for and for Share it is never significant.

${ }^{5}$ No cohort was statistically significant in the Gendereq regression, those aged 26-35 tend to feel it is less important that household responsibilities are shared, and those under 25 years are more positive to government intervention (the base category are those aged 36-45). The results are available upon request.

${ }^{6}$ This is true also when using other classification criteria for income. The results are available upon request.

7 The results are available upon request.

${ }^{8}$ All the tests concerning difference in coefficients between the samples (Norway and Sweden in Table 3) are performed in a pooled sample estimation with all explanatory variables interacted with Sweden. The results are available upon request.

${ }^{9}$ The result (available upon request) regarding high income is robust also when not including the education variables. However, high income is not statistically significant when we define them as the $20 \%$ with highest income.

${ }^{10}$ Our sample is biased towards including highly educated people, and more so in Norway than in Sweden. This, however, does not affect the country differences in gender egalitarian attitudes since the Norway dummy does not change when education is introduced in the stepwise regressions.

${ }^{11}$ Moreover, stepwise regressions show that the sizes and statistical significance of the Norway dummies do not change when more explanatory variables are introduced.

12 That Norway and Sweden are similar according to these factors is illustrated by the fact that the ratio of estimated female to male earned income is 0.81 in Sweden and 0.75 in Norway (the highest two in the OECD) and that Norway is ranked 1 and Sweden 2 in the UNDP Gender Empowerment Index and 9 and 1 respectively in the OECD Gender Institutions and Development Index (OECD Development Centre 2006). ${ }^{13}$ It should be noted that the French data is problematic since the response rate is less than $14 \%$. 